\title{
With Frankness on Wars?
}

\author{
Szczerze 0 wojnie?
}

\begin{abstract}
This article analyses the question of ethics in war circumstances as portrayed in two picturebooks: The Enemy by Davide Cali and Serge Bloch, and I will not by Naila Farouky and Ora Eitan. Aiming to prove that there are some children's books capable of tackling complex moral issues, it looks at the underlying attitudes (for instance, the implied concept of the child reader) and artistic devices employed in these books (such as irony, conceit, rhetoric), which allowed the artists to talk about challenging issues with conviction, frankness, and most importantly, with moral insight.
\end{abstract}

\section{ABSTRAKT}

Artykuł mówi o szczerości jako możliwej postawie artystycznej w książach obrazkowych podejmujących tematykę wojny. Davide Cali i Serge Bloch (The Enemy, pol. Wróg) oraz Naila Farouky i Ora Eitan (I Will Not, pol. Nie będę) buduja skomplikowane narracje emocjonalne i etyczne, wskazując tym samym na potencjalnq dojrzałość młodych czytelników. Autorzy stworzyli ksiqżki wymagające zarówno pod względem artystycznym, jak i etycznym.
KEY WORDS

war, ethics, frankness, picturebooks

\section{SLOWA KLUCZOWE}

wojna, etyka, szczerość, ksiqż̇ki obrazkowe
SPI Vol. 20,2017/4

ISSN 2450-5358

e-ISSN 2450-5366

DOI: 10.12775/SPI.2017.4.004

Artykuły i rozprawy 
Frankness and truthfulness, understood as the qualities to be imbued, feature high on the teachers' and parents' agenda when they are educating children and providing them with "basic ethics." Ironically, the qualities do not feature equally high when it comes to the educators' attitudes toward children. This glaring discrepancy may result from adults assuming socially predetermined roles of leaders and mentors when approaching children. For the fact that they are frequently perceived as those who explore and often undermine the traditional standards of the society, children's books' artists do have a broad range of choices. They can either follow the principal routes of adult-child conduct (often referred to as arising from the concept of the evangelical child) or question or even reverse the existing traditions (thus following the "romantic child" footsteps). This polarity, although very old ${ }^{1}$, still pervades many discourses of contemporary childhood and children's artists, consciously or not, take sides.

Art Spiegelman and Maurice Sendak addressed the polarity debate in their conversations and cartoons published in the New Yorker. ${ }^{2}$ Both considered as powerful yet frequently controversially dealing artists, surprisingly disagreed on the fundamental questions pertaining to the child-adult relationship, namely: "What should children know about the adult world, and when should they know it?"3 Spiegelman's point of view was clear: he wanted to protect kids. Sendak was equally adamant: "You cannot protect kids ... they know everything", he says. ${ }^{4}$ Spiegelman's position revealed his understanding of the concept of a child in evangelical terms, of someone who does not know anything at the beginning and should be instructed and protected. Conversely, Sendak was all for the romantic view of the child, believing in their intuition and understanding. Not sharing Sendak's perspective, Spiegelman still valued his friend's concerns when he observed after Sendak's death: "I think Sendak invested his work with the understanding that the

1 R. Mills, "Perspectives of Childhood," in: Childhood Studies: A Reader in Perspectives of Childhood, eds. J. Mills, R. Mills, London 2000, pp. 7-38.

2 J.L. Zornado, Inventing the Child: Culture, Ideology, and the Story of Childhood, New York 2001, pp. 171-174.

3 Ibidem, p. 172.

4 Ibidem, p. 173. 
distinction between children and adults is probably one of hypocrisy more than anything else." ${ }^{5}$

There are important reasons why I have exposed the polarity issue and the question of protection in this essay. As the supposed theme of the books which are the core of my analysis to follow is war, the above considerations seem the more powerful and the answers to the relevant questions arising, more urgent. War for many years was considered a taboo topic in children's literature, and while it has ceased to be viewed as such, it cannot automatically be concluded that any way of discussing war for or with children is valid. The artistic form and perspective the artists take when bringing up war are still under many-sided scrutiny. The Enemy by Davide Cali and Serge Bloch ${ }^{6}$ and I Will Not by Naila Farouky and Ora Eitan ${ }^{7}$ are two contemporary examples of visual literature which look at war, both factual and fictional, with eyes morally open. The indisputable frankness and truthfulness of approach toward both the theme and the audience situate the books on Sendak's side, with the artists honestly sharing what they know and opening a discussion of war and beyond that is both experientially and ethically informed.

5 S. Weiss, "Art Spiegelman Discusses Maurice Sendak," Nerw Yorker, May 9, 2012, <http:/www.newyorker.com/culture/culture-desk/art-spiegelman-discusses-maurice-sendak> (access: 24.01.2017).

6 D. Cali, S. Bloch, The Enemy, Wilkins Farago, Elwood 2007. I have studied and compared a number of editions and translations of this picturebook, originally published in French (L'ennemi, Sarbacane, Paris 2006). From all of the editions, one curiously stands out, and it is the American version (The Enemy, Schwartz \& Wade, New York 2009), which is drastically abridged, both regarding contents and meaning making potential. The text has been noticeably shortened, but this decision has not affected the essence of the book so much. It is the omission of all the illustrations portraying the generals that may and most probably does have an impact on the book's interpretation. Without the images of people of power, the originally intended double sense of the titular "enemy" becomes impossible, and the soldier's considerations about the circumstances of ending the war turn to be one-sided and personal, not political. Regrettably, the irony and clear-sightedness of the original book are lost in the American translation (or more accurately, adaptation).

7 N. Farouky, O. Eitan, I Will Not, New York 2015. 


\section{Hic et nunc}

Both books, if necessarily very different in many aspects, share a number of essential qualities, apart from the already mentioned principles of frankness and truthfulness. Both, although in a variety of ways, communicate a nagging sense of immediacy. Frequently, for reasons that can be defined as "sparing the child" and lessening the emotional impact of the story for the young reader, more traditional war books are set in the (often remote) past. These books do not adopt the common historical perspective most children's war books take. While The Enemy employs a kind of a historical, World War I costume, which can be seen in the soldiers' uniforms and the idea of trenches, it does so symbolically rather than realistically, and the concept of war showing from behind the costume is present-day. The modern feel and the atmosphere of immediacy are also achieved through the visual technique resembling comic drawings or press caricature. The other book, I Will Not is even "closer" to the contemporary world and its affairs as it directly comments upon the renewal of the armed conflict in the Gaza Strip in 2014. In both books war is an event or phenomenon which affects the speakers right now as a current conflict and they comment or react instantly. The past does not occupy any significant position, and it is the present and the future which are of utmost importance.

The sense of "now" pervades both texts. The Enemy, in a seemingly unpolished style, opens in medias res, showing a few doublespreads of text and images before the title page proper:

There is a war on. Here's something that could be a desert... in which there are two holes. In the holes, two soldiers. They are enemies. ${ }^{8}$

The text before the title page is a third person narrative, introducing the scene and the two characters, the soldiers, who are enemies. When the title page comes, the narration switches to the first person perspective, making one of the soldiers the protagonist and the other, his enemy. Notwithstanding, the style remains the same; the sentences are simple, at times they even sound simplistic as if the narrators needed to make sure the message is communicated clearly and unambiguously.

8 D. Cali, S. Bloch, The Enemy, op. cit. 
The story's details are kept to a minimum, and the reader's associations with the style of telegrams are possible and perhaps justified.

The text of I Will Not constructs the sense of "now" in a more personal way, through a first person disturbed and determined voice reciting a poem. The predetermined limitation of the grammatical tenses used (in her poem, Farouky uses mostly present simple and future simple tenses) heightens the evocative power of the text. Similarly to the text of The Enemy, this text also may seem unpolished or even crude. This very crudeness metaphorically adds to the frankness of the address and portrayal of war. A text which would be eloquently polished and much more sophisticated might reveal too much of concern for its form and pretence. When time is short, texts remain unpolished, and in both books, of course, the time is short. The sense of immediacy is built not only through the time schemes, grammar, and style. The narrator and speaker choose a subjective, personal perspective, namely the first person voice for the central part of their texts and thus they intensify the experience of "here and now."

\section{The Enemy: "All the world's a stage"}

It might seem that the first person point of view will be used to evoke more sympathy or empathy for the tellers. On the contrary, instead of metaphorically easing their burden, it has been used to add more and explore their sense of responsibility and moral sensitivity. The Enemy, disentangling the mechanisms of war, draws attention to the questions of ideology, manipulation, and the individual moral response. The theme of manipulation is intelligently interwoven into the structure of the book due to the dramatic convention the authors use. In The Enemy, Cali and Bloch decide to de-metaphorise the military oriented phrase, "Theatrum belli." Their return to the literal meaning of the metaphor allows them to probe its constructive potential in the context of the drama presented. The opening section of the picturebook, which begins right after the first endpapers, is the prologue to the core story. This part of the book resembles the chorus part in the ancient tragedy. The title page shows the protagonist of the drama as if waiting for the show to start. The protagonist is a lone soldier crouching on a stairs-shaped platform and his schematic body language and facial expression address suspension. The red curtains hanging at both 
sides of the stage visually dominate the scene, occupying ninety percent of the doublespread surface. They symbolically (note the red colour and their size as compared to the miniature size of the soldier) and metaphorically (the "actor and stage" tropes) encapsulate the soldier's position. The layout of the page and the reciprocal orientation of its constructive elements also connote the idea of the soldier being merely an easy, self-conscious target. On their way to explore and deconstruct the theatre metaphor, the readers arrive at the questions of the drama's audience and the director(s) of the play.

The Enemy works on multiple levels, and this very quality is already mirrored in the book's title. The word "enemy" most obviously denotes a soldier of the opposing army, and for a large part of the story, as if against the creeping clues of counter-interpretation, this reading remains valid. The drama unfolds around the ideological anatomy of the enemy: firstly, his personality and cruel nature, as represented in the Red Book (a manual every soldier gets at his joining the army) and then, the protagonist's realisation that the image of the enemy is fabricated for the purpose of the war. The revelation comes when the soldier discovers an almost identical Red Book in the enemy's trenches, with the only exception that the enemy's portrait in the other Red Book has the soldier's face. The revelation becomes the climax of the drama as it brings understanding, both to the protagonist and the audience, that war is a manipulation game designed by the generals, governments or the people of power. The mechanisms involved in the brainwashing and lies production are the same, while the only difference is the image of the concrete soldier. This particular moment allows for a retrospect and reinterpretation of the title of the book and the previously neglected hints (for instance, the image on the book's cover). The true enemy turns out to be the symbolical figure of the general: over-conscious, indiscriminate, and incessantly buoyant.

Consequently, this moment of revelation changes the course of events. When the real antagonist has been uncovered, the soldier begins to act individually, as if the understanding helped unblock his moral thinking and ultimately, critically affected his moral conduct. The soldier decides to end the war on his terms by writing a peace message to the other soldier (no longer called "the enemy" in the text) and sends it in a bottle. The drama seemingly ends here as there are no more pages bar the final endpapers. The story intriguingly 
continues, as the endpapers show two soldiers missing from the soldier-patterned design. The authors leave the audience with a number of unspoken hypotheses and an open ending.

The possibly happy ending may imply that the soldiers managed to communicate via the message bottles (the "false" enemy also sent a similar peace message to the protagonist) and deserted their armies, no longer involved in the wars. It may also prompt a universal observation that once you understand the mechanisms behind wars, you no longer "play the game" and are immune to the manipulation. However, a more dramatic version of the ending is also plausible: both soldiers got killed by order of their generals because of their insubordination or for the fact that they have seen through the manipulation. No ending is pessimistic from the moral point of view, which makes the story even more evocative and compelling. The soldier, although at first an apparent victim, turns out to be the hero of the drama, regaining, along with the understanding, his moral power and stability, whichever the ending. One way or another, the actor leaves the stage (of war).

\section{Will Not: A deliberate suppression of hatred}

Paradoxically, I Will Not, a picture book rooted in a real event of a still unexpired conflict in the Gaza Strip, uses much more "literary" devices than The Enemy. While the fictional reality of The Enemy has been represented with primarily non-fiction oriented tools, such as the telegraphic style of the verbal text or the economic drawings related to caricature, I Will Not reaches for forms and styles much closer to the fictional mode, a dramatic monologue convention for the text and elaborate metaphorical mixed-media illustrations.

Whereas the idea of the book started as a poem by Naila Farouky, it soon developed further, as it turned out the Ora Eitan's images provide the textual canvas with more depth and a stronger voice. Also, the paratextual dimension of I Will Not augments the book's symbolism and meaning potential, as Farouky is a Palestinian writer, and the illustrator, Eitan —an Israeli artist. The text has been simultaneously printed in three language versions: English, Arabic, and Hebrew, thus preparing ground for more advanced considerations of a peaceful resolution of the conflict through communication, not aggression. 
The text of I Will Not challenges the perception of an almost natural dichotomy of victim and aggressor since it does not discuss this aspect at all. The voice is simultaneously situated on both sides of the conflict, where it sounds equally genuine and valid, and in this way the difference between "self" and "the other" is erased. The text also challenges one of many modes of war representation which typically concentrates on action and events, heroes and villains, but often fails to understand and embrace the beliefs and attitudes that underpin war. Indirectly, through the focus on the unmediated state of affairs, the pain and suffering, and both, the immediate and long-lasting consequences of hatred, the text lays bare the futility and moral wrongness of war. The text re-evaluates a number of concepts, such as courage, coward, patriot, and traitor. It also quotes other than the speaker's points of view, but shows them to be morally deficient, for the obvious reason that they lead to suffering and death, to evil. Of human beings' positive and negative moral duties, the negative ones should always take precedence, on the basis of primum non nocere ethical rule. ${ }^{9}$ The frankness and tenacity of address, which can be seen for example in the embedding of dissonant "other" voices in the monologue and the speaker's daring and unambiguous replies to them, help the speaker "win" the peace plea. Representing the attitude of moral certainty, a deliberate choice of suppressing one's hatred, with a simultaneous exposure of the cultural and moral background of the decision (as for instance in: "I will not call for death, no matter how much it aches") gives the reader a powerful impulse for ethical growth.

The images have been created as a visual response to the poem, and as such, they are chronologically secondary. Nonetheless, their expressive power equals or even surpasses that of the text. Eitan employed the technique of overlayers, using both painting and collage. The overlaying of shapes, some of which are realistic, some distorted, creates the world of uncertainty, utterly defocused, while the muted colours and blurred contours symbolically reflect the nature of the difficulties portrayed. In relation to the text, the images also function as a portrayal of a mental landscape of the speaker and their apparent lack of finish or neatness mirrors the text's unpolished quality.

9 See B. Chyrowicz, O sytuacjach bez wyjścia w etyce, Kraków 2008, p. 296. 


\section{Visual literature and critical ethics}

The Enemy and I Will Not generically belong to visual literature, a group of artistic texts which communicate meaning through word and image. Although both resulted from a collaboration between the writer and the illustrator, the ultimate artistic effects are more than a sum of the textual and visual qualities. In both books, the word and image create a unique relationship of interanimation, in which the verbal significantly influences or even transforms the visual and vice versa. Neither Bloch in The Enemy nor Eitan in I Will Not duplicates the meanings the texts offer, but they rather work to expand the symbolic or metaphorical potential of the words or create additional layers of significance. Bloch in his drawings is first to reveal the double (or the true) meaning of the titular "enemy" on the cover of the book, his visual sarcasm and irony are also faster to grasp by the audience. The images gradually build and support the concept of the theatre (the de-metaphorised theatrum belli is virtually absent from the text), and they are more direct than the text in presenting the moral awakening of the protagonist. In Eitan's visual response to Farouky's poem painful emotions such as unease or fear, take precedence over the clarity of moral vision represented by the text. The images intelligently communicate the fact that finding one's moral ground is never easy, especially in dramatic circumstances.

The different tensions necessarily occurring between the word and the image, if consciously exploited by the artists, may prove beneficial for the meaning potential of the work, as we can witness in the case of the books studied in this article. Although we can observe a high degree of collaboration between the artists and a frequent unity of ideas, the media in which they communicate the ideas (i.e., the word and the image) are still in many ways separate. Apart from the fact that the readers possess different levels of reading and decoding competences, they also exhibit different sensibilities. For many, such a combination of signifying systems and layers of meaning as the word and the image inter-animation offers may prove an intellectual challenge and artistically rewarding experience.

The Enemy's surface simplicity and obviousness are misleading, its seemingly schematic text and drawings conceal non-schematic thinking about the ideology and war, and, ultimately, the hidden agenda of the picturebook. The other book, I Will Not, proves a different type of 
a challenge, that of a political and ethical category. Its text seems not to need the assistance of the images, as it is self-contained on its terms. The images critically expand the emotional overtone of the poem, adding intensity and depth to its clarity and power. Both books through their structure and the view of the theme can actively engage the reader of any age in the cultivation of critical thinking which in turn, in the case of these particular books, encourages critical ethics.

I Will Not as well as The Enemy only to a certain extent discuss wars. Both books use real life and fictional military conflicts to explore the ethical stances and the metamorphoses of the speakers, narrators or the characters portrayed. Both employ sophisticated artistic tools to demonstrate the obstacles and difficulties experienced by the characters. In The Enemy, the most powerful negative influences are the impact of ideological instruction designed by the soldier's authorities and his temporarily limited awareness and knowledge of the mechanisms behind the manipulation. Then, in I Will Not, the most difficult problem to face is the real or imagined pressure of the compatriots. The books lead towards important ethical observations: an ill-conceived idea of power in one case, and hatred, in the other, are the true enemies. The books, taking the circumstances of wars into consideration, in fact, talk, with frankness, about possibly ethical human beings.

\section{Bibliography}

Cali D., Bloch S., The Enemy, Wilkins Farago, Elwood 2007.

Chyrowicz B., O sytuacjach bez wyjścia w etyce, Znak, Kraków 2008.

Farouky N., Eitan O., I Will Not, StarWalk Kids Media, New York 2015.

Mills R., "Perspectives of Childhood," in: Childhood Studies: A Reader in Perspectives of Childhood, eds. J. Mills, R. Mills, Routledge, London 2000, pp. 7-38.

Weiss S., "Art Spiegelman Discusses Maurice Sendak," New Yorker, May 9, 2012, <http://www.newyorker.com/culture/culture-desk/art-spiegelman-discusses-maurice-sendak>.

Zornado J.L., Inventing the Child: Culture, Ideology, and the Story of Childhood, Garland, New York 2001.

\section{ADDRESS FOR CORRESPONDENCE:}

Dr Magdalena Sikorska

Kazimierz Wielki University in Bydgoszcz, Poland

magsikorska@o2.pl 